\title{
Frictional stability of porous tuff breccia under subsurface pressure conditions and implications for shallow seismicity
}

\author{
Kazuo Mizoguchi ${ }^{1 *}\left(\mathbb{D}\right.$, Shin-ichi Uehara ${ }^{2}$, Takehiro Hirose ${ }^{3}$ and Sachiko lizuka ${ }^{4}$
}

\begin{abstract}
Thick sediment layers frequently cover the Japan islands' surface, and their frictional properties significantly affect the shallow slip behavior that occurs during earthquakes. However, laboratory data on the properties of the shallow zone remain limited. We collected tuff breccia samples from deep borehole cores in the Miocene "Green Tuff" formation, a major surface cover, and performed velocity-stepping friction tests on these samples under in situ stresses of 2 to $20 \mathrm{MPa}$ to assess the velocity dependence of their frictional strength. The samples exhibit predominantly frictionally stable, velocity-strengthening behavior over the range of normal stresses tested, which supports the hypothesis that shallow sediment layers are seismically quiescent. This result is consistent with the low seismicity and attenuation of coseismic slip occurring in the shallow zone that is observed during regional earthquakes. Microstructural observations of the postmortem samples using optical and scanning electron microscopes indicate a fabric transition from boundary shear localization to distributed cataclastic flow with increasing normal stress. Our laboratory investigation of the depth-variable distribution of the frictional velocity dependence of a shallow sediment layer would provide further insight into the mechanical role for earthquake rupture dynamics and shallow seismicity.
\end{abstract}

Keywords: Tuff breccia, Frictional strength, Velocity-dependent friction, Shallow seismicity, Sediment cover, Earthquake dynamics

\section{Introduction}

Seismological observations have shown that earthquake activity is largely concentrated in the upper portion of the brittle crust, named the seismogenic layer (Sibson 1983). The thickness of this layer varies from 10 to $50 \mathrm{~km}$ and is strongly dependent on the thermal structure in different tectonic settings. This thickness is a critical index to estimate the depth extent of the fault rupture area and the proportional seismic moment release (magnitude) of potential future earthquakes (e.g., Ito 1999; Maggi et al. 2000; Nazareth and Hauksson, 2004). From the view point of the rock deformation mechanism, the bottom

\footnotetext{
*Correspondence: k-mizo@criepi.denken.or.jp

${ }^{1}$ Central Research Institute of Electric Power Industry, 1646 Abiko, Abiko,

Chiba 270-1194, Japan

Full list of author information is available at the end of the article
}

of the seismogenic layer is considered to correspond to a transition zone from the frictional/brittle regime to the plastic regime, as temperature increases with depth (Sibson 1982, 1983; Fredrich et al. 1989). After the introduction and development of the rate- and state-dependent friction constitutive law, the sign of the frictional response to a transient increase in the sliding velocity has been used as a critical benchmark of earthquake instability (Dieterich 1979; Ruina 1983). While a positive sign represents velocity-strengthening, which promotes stable slippage of the fault, a negative sign represents velocity-weakening, which leads to unstable earthquake slips (Marone 1998; Scholz 1998). It is suggested that the lower boundary of the seismogenic layer marks the transition that occurs with depth from an unstable velocityweakening field to a stable velocity-strengthening field (Tse and Rice 1986; Blanpied et al. 1991). Meanwhile, 
above the seismogenic layer, there is a seismically quiescent zone in the subsurface that is several kilometers thick (Doser and Kanamori 1986; Marone and Scholz 1988).

The presence of the shallow zone has been shown to significantly influence the fault behavior during dynamic earthquake ruptures, and its resultant properties of strong ground motion (Marone et al. 1991; Brune and Anooshehpoor 1998; Scholz 1998; Day and Ely 2002). For large earthquakes, a fault slip likely nucleates near the base of the seismogenic layer (Sibson 1982, 1983; Das and Scholz 1983), and then propagates upward as well as downward along the faults (Sibson 1983; Scholz 1998). Detailed studies on coseismic slip distributions determined from slip inversions of geodetic data have indicated that when a rupture enters the shallow zone, further upward migration of the rupture tends to be evidently hindered, resulting in a decrease in coseismic slip toward the ground surface (Wald and Heaton 1994; Simons et al. 2002; Fialko et al. 2005). Over the last decades, the cause of such shallow slip deficits has been discussed, especially in relation to the frictional properties of the materials that make up the shallow zone (Marone et al. 1991; Scholz 1998; Fialko et al. 2005; Zinke et al. 2014). It was found that earthquake cycle simulation involving depth variation in velocity-dependent friction model including a shallow velocity-strengthening regime can reproduce the decrease in on-fault slip toward the surface (Marone et al. 1991; Rice 1993). Another explanation on the shallow slip deficit in addition to the frictional properties of the fault plane is that dispersed off-fault deformation of the protolith medium during the coseismic as well as interseismic periods can accommodate a portion of expected elastic strain energy, comparable to the portion accommodated at deep depths, because of the low rigidity and the velocity-strengthening property of the medium under shallow conditions (Fialko et al. 2005; Kaneko and Fialko 2011). When the rupture is confined to the shallow zone without breaching the surface, the near-field ground motion is amplified (Somerville 2003; Pitarka et al. 2009), thereby causing more severe damage to the infrastructure in the inland earthquake source areas. For subduction zone earthquakes, whether the rupture propagation in the shallow part is suppressed or not is directly linked to the generation of devastating tsunamis (Hyndman et al. 1997; Moore et al. 2007). For instance, several experimental studies have reported the frictional properties of samples retrieved from the shallow part of the Japan trench subduction zone in order to investigate why during the 2011 Tohoku-Oki earthquake the rupture that accompanied an extraordinary large slip passed the shallow part, traditionally thought to be frictionally stable, and reached the sea floor to generate huge tsunamis (Fujiwara et al. 2011; Ito et al. 2011; Kodaira et al. 2012; Ujiie et al. 2013; Ikari et al. 2015; Sawai et al. 2017). Elucidating the frictional properties of the crustal shallow zone is essential to understand earthquake rupture process and to further improve our capability to assess seismic hazards. However, our knowledge of these frictional properties remains incomplete owing to the paucity of laboratory data other than data on major continental faults and plate boundary faults (Verberne et al. 2010; Carpenter et al. 2011, 2015; Boulton et al. 2012; Ikari et al. 2015; Niemeijer et al. 2016).

For the Japanese island arc, where intraplate crustal earthquakes frequently occur (Matsuda 1977; Wesnousky et al. 1984), more than $50 \%$ of the surface is dominated by Quaternary and Neogene clastic and volcaniclastic $\mathrm{km}$-scale-thick sediment layers that fill the fore-arc and back-arc basins and the volcanic front region and overlie crystalline or metamorphic basement rocks (von Huene et al. 1982; Murata and Kano 1995). In this study, we aim at investigating the rate-dependence of the frictional resistance of a thick sediment layer that overlies the basement rocks, and widely covers the inland earthquake source area. To perform this investigation, we used velocity-stepping friction tests in a bi-axial shear configuration, under pressure conditions of up to $\sim 2 \mathrm{~km}$ in depth. The friction tests were conducted on porous tuff breccia samples collected at a 60-m depth from a borehole drilled in the Miocene "Green Tuff" formation, a thick deposit over the Japan Sea side of Northeast Japan (Huzioka 1963; Kikuchi et al. 1991). We analyzed the experimental data with the Dieterich's rate- and state-dependent friction constitutive law (Dieterich 1979, 1981) to obtain the variation in friction parameters as a function of normal stress. In addition, microstructural observations of the deformed samples allowed us to discuss the relationship between the variable friction behavior and the deformation mechanism. The laboratory-derived shallow zone properties we present here enable more rigorous discussion on the impact of the shallow zone on slip behavior during an earthquake.

\section{Experimental procedures Samples}

The samples used in this study were taken from porous andesitic tuff breccia from the Anamizu (Iwaine) Formation on the shore of the Noto Peninsula in central Japan (Fig. 1). The pyroclastic rock is a member of the "Green Tuff" Formation, which comprises several thousand meters of thick sequences of volcaniclastic deposits resulting from submarine volcanism associated with the opening of the Japan Sea from the late Oligocene to the middle Miocene (Kikuchi et al. 1991; Sato and Amano 1991; Kano et al. 2007). These deposits are distributed 


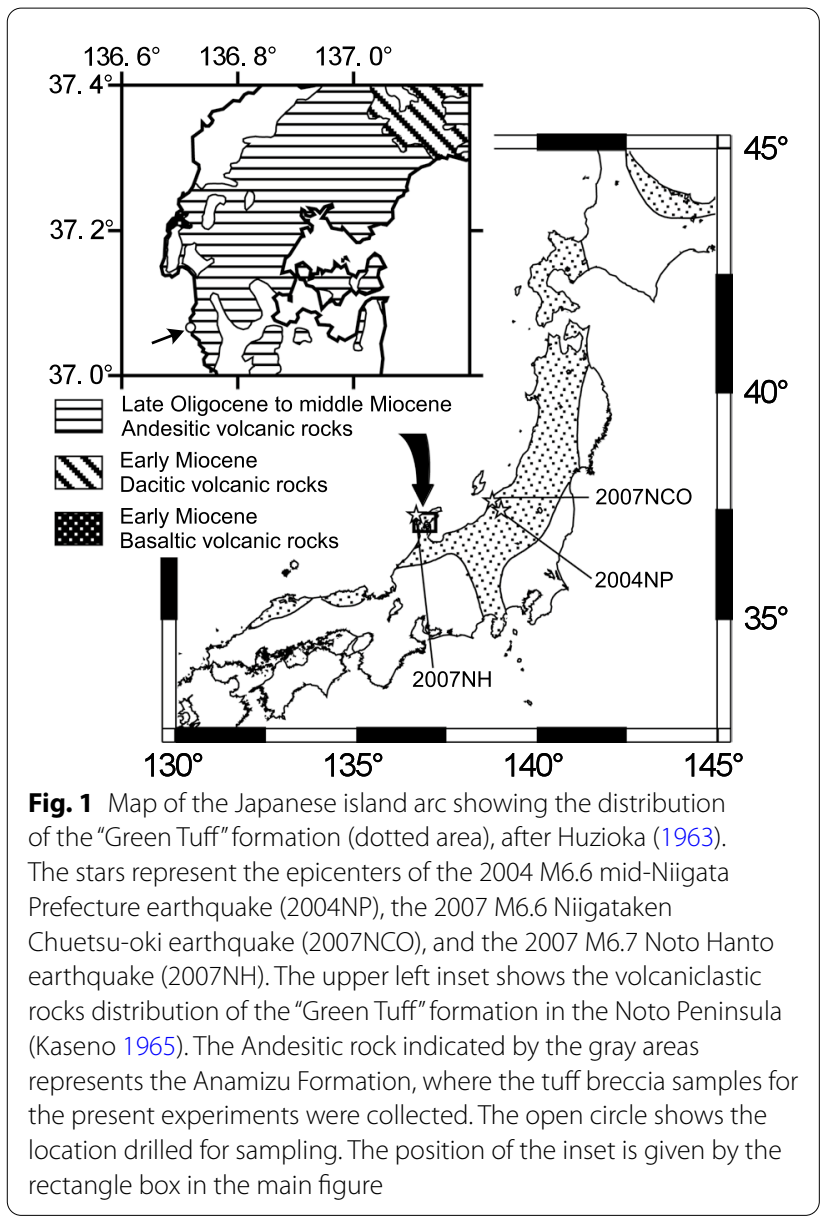

over an area of $44,000 \mathrm{~km}^{2}$, corresponding to more than $10 \%$ of the island arc, along the Japan Sea coast (Huzioka 1963; Murata and Kano 1995). The "Green Tuff" area has experienced three large earthquakes in the last two decades including the 2004 M6.6 mid-Niigata Prefecture earthquake, the 2007 M6.6 Niigataken Chuetsu-oki earthquake, and the 2007 M6.7 Noto Hanto earthquake, according to the database of the Japan Meteorological Agency.

Stratigraphic studies have shown that the Anamizu Formation from which the experimental samples were collected is $\sim 2 \mathrm{~km}$ thick in the Noto region (Kaseno 1965; Ozaki et al. 2010). For the friction experiment, fresh core samples of tuff breccia retrieved from the Miocene Anamizu Formation at a depth of $60 \mathrm{~m}$ following drilling in the middle western coast of the Peninsula (Fig. 1) were used. The tuff breccia samples were composed of conglomerate-sized andesitic fragments in a matrix of tuff. We used the matrix part of the sample for the friction experiment. Using optical microscopic observation combined with powder X-ray
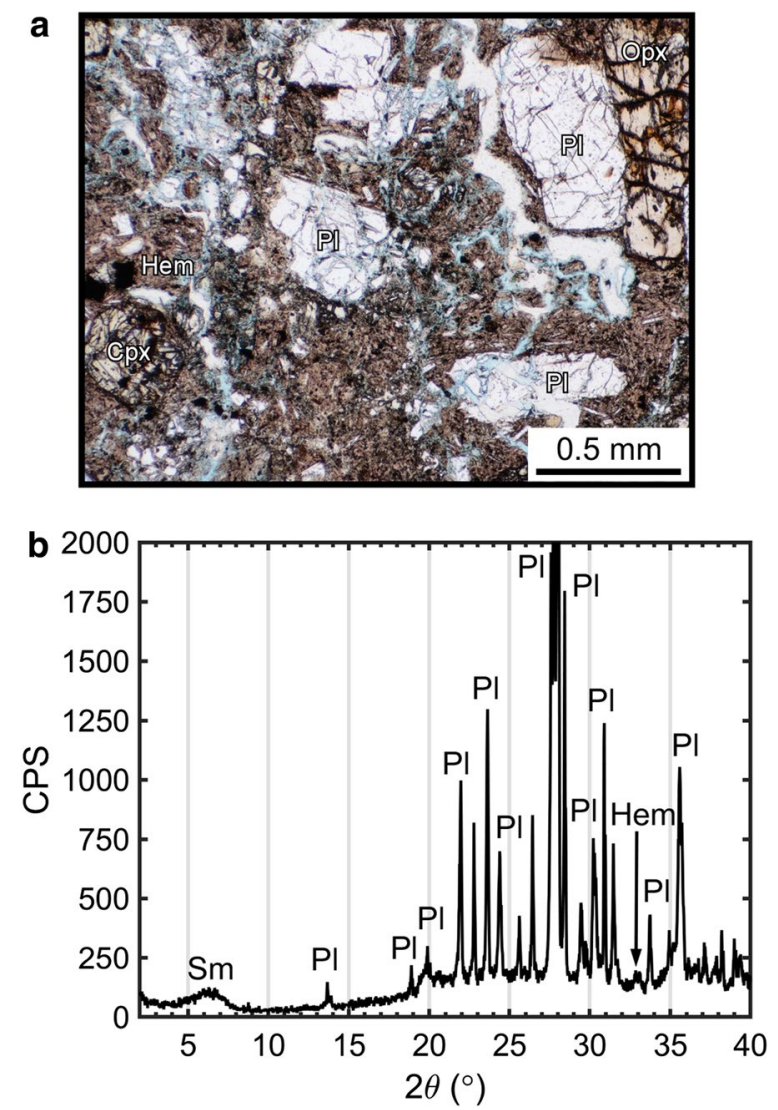

Fig. 2 Porous tuff breccia sample used in the experiments. a Photomicrograph of the tuff breccia sample under plane-polarized light. $\mathbf{b}$ X-ray diffraction profile of the experimental sample. The X-ray diffraction analysis was done under the following conditions: a Cu anode, acceleration voltage of $40 \mathrm{kV}$, current of $20 \mathrm{~mA}$, step size of $0.02^{\circ}$, and scan speed of $2^{\circ} / \mathrm{min}$. Pl, plagioclase; Opx, orthopyroxene; Cpx, clinopyroxene; Sm, smectite; Hem, hematite

diffraction analysis (Fig. 2a, b), we confirmed that the tuff matrix was characterized by phenocrysts of plagioclase, orthopyroxene, and clinopyroxene with a grain size ranging from 0.3 to $1.1 \mathrm{~mm}$ in a fine-grained groundmass of plagioclase, clinopyroxene, and alteration products of smectite and hematite into which volcanic glasses were chemically transformed. The mineral composition was plagioclase $(\sim 57 \%)$, orthopyroxene $(\sim 4 \%)$, clinopyroxene $(\sim 8 \%)$, smectite $(\sim 17 \%)$, and hematite $(\sim 8 \%)$. The porosity of the rock, estimated by measuring the weight difference between completely dried and water-saturated samples under atmospheric conditions, ranged between $19.5 \%$ and $26.1 \%$. In addition, the bulk density, which is the mass divided by the volume including any pore space, was calculated to be $2030 \pm 80 \mathrm{~kg} / \mathrm{m}^{3}$. 


\section{Bi-axial double-direct shear-loading apparatus}

To perform the friction tests in this study, we used a newly installed Bi-Axial double-direct SHear loading apparatus (BASH), designed at the Central Research Institute of Electric Power Industry and manufactured by Marui Co., Ltd (Japan). The three main components of the apparatus are a shear-loading unit with a maximum load of $1000 \mathrm{kN}$, a stroke of $50 \mathrm{~mm}$, and sliding velocities ranging from $0.1 \mu \mathrm{m} / \mathrm{s}$ to $5 \mathrm{~mm} / \mathrm{s}$; a specimen chamber unit that is $500 \mathrm{~mm}$ in length, $300 \mathrm{~mm}$ in height, and $100 \mathrm{~mm}$ in width; and a normal load unit with a maximum load of $600 \mathrm{kN}$ (Fig. 3a).

In the shear-loading unit, a rotary shaft is connected between a 22-kW servo-controlled electric motor with

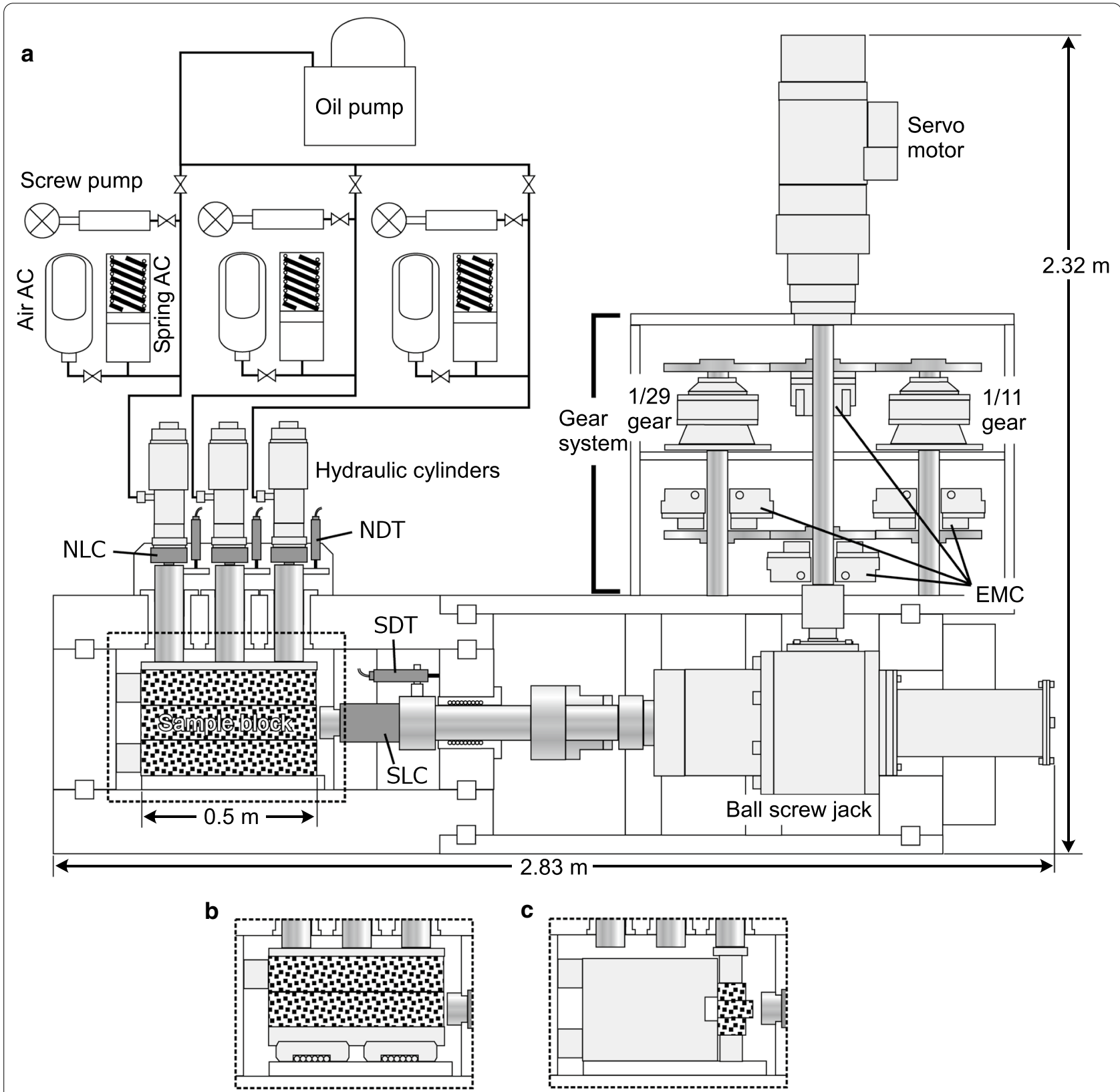

Fig. 3 The bi-axial double-direct shear-loading apparatus (BASH). a Schematic diagram showing the bi-axial compression apparatus built at CRIEPI, including a sample assembly in a double-direct shear configuration for a $50-\mathrm{cm}$-long rock specimen. $\mathbf{b}$ Single-direct shear sample assembly for long rock specimens. c Double-direct shear sample assembly for short rock specimens used in this study. SLC, shear load cell; SDT, shear displacement transducer; NLC, normal load cell; NDT, normal displacement transducer; AC, accumulator; EMC, electromagnetic clutch 
a maximum rotation speed of $1500 \mathrm{rpm}$ and an optionally attached $1 / 4$ reduction gear and a $1000 \mathrm{kN}$ ball screw jack, via a gear system for adjusting the rotation speed (Fig. 3a). The gear system provides a direct line and two speed-down output lines with ratios of $1 / 11$ and $1 / 29$, respectively. The rotation from the motor is converted by the screw jack to linear motion in the horizontal shaft, thus exerting a shear load on the facing rock sample in the chamber. The three speed lines are engaged manually using the combination of an electromagnetic tooth clutch and three single-disc electromagnetic clutches to produce the target sliding velocity of the horizontal shaft. A load cell (SLC in Fig. 3a) with a capacity of $1000 \mathrm{kN}$ and a resolution of $0.6 \mathrm{kN}$ for shear force and a strain gaugetype displacement transducer (SDT in Fig. 3a) with a capacity of $100 \mathrm{~mm}$ and a resolution of $0.04 \mathrm{~mm}$ for the sliding distance are positioned on the shear-loading shaft. For the low-stress experiments performed in this study, we temporarily installed a $100-\mathrm{kN}$ load cell with a $0.05-$ $\mathrm{kN}$ resolution for the shear stress and an 80-mm laser displacement sensor with a $0.25-\mu \mathrm{m}$ resolution for the shear displacement on the shaft.

The sample chamber can host three rock samples with contact areas of $50 \mathrm{~cm} \times 10 \mathrm{~cm}$ and a thickness of $10 \mathrm{~cm}$. The central block is sandwiched between the side blocks and pressed by the horizontally moving shaft connected to the screw jack in the double-direct shear configuration (Fig. 3a). When we conduct the single-direct shear friction experiment, the lower stationary rock block is replaced by a stainless-steel block with similar dimensions involving a low-friction roller at the bottom (Fig. 3b). For small rock samples with dimensions of $10 \mathrm{~cm} \times 5 \mathrm{~cm}$ such as those used in the present study, the extra assembly shown in Fig. $3 \mathrm{c}$ is installed into the chamber.

The normal load unit comprises three $200-\mathrm{kN}$ hydraulic cylinders, with each containing a $660-\mathrm{mL}$ air accumulator for oil pressure levels less than $45 \mathrm{MPa}$, a $17.6-\mathrm{mL}$ spring-charged accumulator for higher pressure levels, and a manual screw hydraulic pump for stabilizing the oil pressure fluctuation that is caused by a fault-normal dilatancy/compaction of $\leq 5 \mathrm{~mm}$ during shear experiments. A 70-MPa hydraulic motor-driven pump supplies pressurized oil to the cylinders. The hydraulic cylinders are aligned parallel to the shear direction at an interval of $17 \mathrm{~cm}$, with the oil pressure in each cylinder controlled independently. This allows the application of a normal load on a $50-\mathrm{cm}$-long rock sample in a spatially uniform or non-uniform manner. A load cell (NLC in Fig. 3a) with a capacity of $200 \mathrm{kN}$ and a resolution of $0.1 \mathrm{kN}$ for normal force is mounted on the bottom of each hydraulic cylinder. A strain gauge-type displacement transducer (NDT in Fig. 3a) with a capacity of $50 \mathrm{~mm}$ and a resolution of $0.02 \mathrm{~mm}$ for normal distance is attached to the normal loading shaft, through which a normal force is transmitted from each hydraulic cylinder to the upper face of the sample block. Among the three cylinders, that on the right was only used to press the small samples in the present study.

Data from all sensors (i.e., the shear load, shear displacement, normal load and normal displacement) are recorded during the experiments using a 24 bit analogto-digital converter at a sampling rate of $24 \mathrm{kHz}$. This is typically decimated down to a lower sampling rate $(100 \mathrm{~Hz}$ in the present study) after the data acquisition.

\section{Friction experiments}

For the friction experiments, we prepared 5-mm-thick squared rock plates from the core samples of the tuff breccia. Since the tuff breccia core samples were consolidated enough that they could be easily handled, they were cut into squared plates, with the end surfaces facing the granite blocks polished using a high-precision surface grinding machine to ensure flatness and parallelism within $12 \mu \mathrm{m}$. Before being inserted into the apparatus, the samples were vacuumed and immersed in deionized water for more than $16 \mathrm{~h}$, which was long enough to saturate the internal pores with water. In our experiments, we used water-saturated samples to simulate the in situ (wet) conditions at depth.

The friction experiments were performed using the bi-axial loading apparatus described above in a doubledirect shear configuration in which two 5-mm-thick squared plates were placed between a central granite block and two side granite blocks, across contacting interfaces with dimensions of $48 \mathrm{~mm} \times 48 \mathrm{~mm}$ (inset in Fig. 4a). The surfaces of the three granite blocks were ground and roughened with \#14 $\mathrm{SiC}$ abrasive to induce deformation within the plate sample, and not along the boundary between the plate sample and the granite block. Shear deformation in the two plate samples was attained through the movement of the central block against the stationary side blocks. In the sample chamber, our thin plate samples sandwiched between the forcing granite blocks were not confined by a jacket, and the end surfaces were directly exposed to the atmospheric environment, indicating that the pore pressure in the sample could be implicitly controlled to be equal to atmospheric pressure.

A series of velocity-stepping friction tests was conducted under atmospheric conditions at normal stresses ranging from 2 to $20 \mathrm{MPa}$. These stresses simulated the ambient effective pressure conditions at depths down to the bottom of the Anamizu Formation (a 2-km depth), assuming $10 \mathrm{MPa} / \mathrm{km}$ from the bulk density of the samples and from the water density $\left(1000 \mathrm{~kg} / \mathrm{m}^{3}\right)$ (Table 1$)$. 

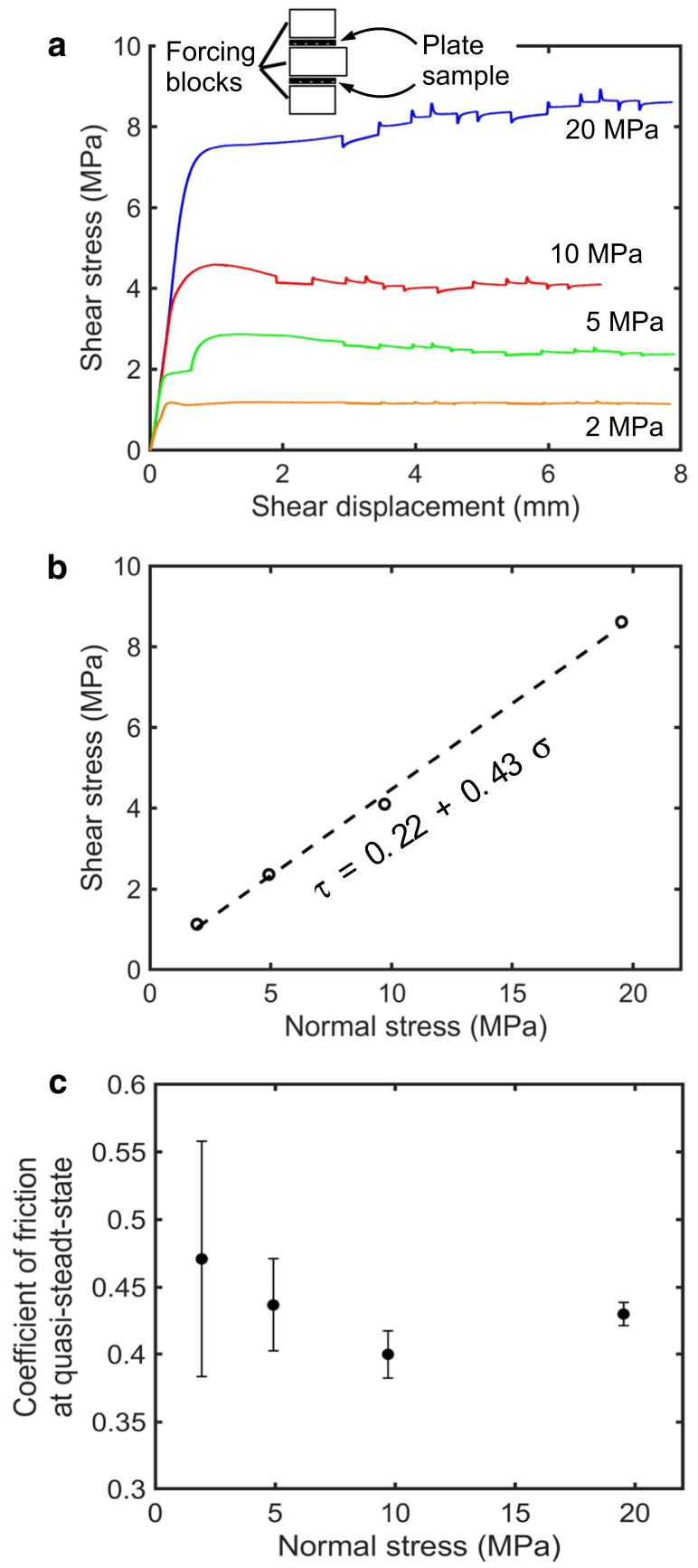

Fig. 4 Mechanical data from velocity-stepping experiments conducted at elevated normal stresses. a Shear stress versus shear displacement for the samples deformed at 2 (orange), 5 (green), 10 (red) and $20 \mathrm{MPa}$ (blue). The upper left inset displays a schematic of the double-direct shear configuration. b Steady-state shear stress ( $\tau$ ) as a function of the normal stress $(\sigma)$ at a $1.5-\mathrm{mm}$ shear displacement where a quasi-steady-state is achieved. The friction coefficient and cohesive strength determined by a least-square fit (coefficient of determination R2 $=0.9975$ ) with the Mohr-Coulomb linear equation (dashed lines) were $0.43( \pm 0.02)$ and $0.22( \pm 0.17)$, respectively. c Quasi-steady-state friction coefficient corrected for the cohesive strength $(0.22 \mathrm{MPa})$ as a function of normal stress
The normal stress $\left(\sigma_{\mathrm{n}}\right)$ was kept constant during the sliding, while the shear stress $(\tau)$ was increased to deform the plate samples. The normal and shear stresses, shear displacement, and sample thickness data were recorded at $100 \mathrm{~Hz}$ during the experiments. After the start of the experiment, the plate samples were first sheared to a displacement of $2 \mathrm{~mm}$ or larger at $1 \mu \mathrm{m} / \mathrm{s}$ until the shear stress reached a steady state. We then changed the sliding velocity in stepwise fashion from 0.1 to $100 \mu \mathrm{m} / \mathrm{s}$, with at least a $0.3-\mathrm{mm}$ displacement in each step, to evaluate the dependence of the friction parameters on the velocity. After the experiments, the deformed plate samples were thin-sectioned parallel to the shear direction in order to observe the microstructural changes associated with different normal stresses using optical and scanning electron (JEOL JSM-7001F) microscopes.

The velocity-stepping friction data were analyzed using an iterative least-square inversion modeling technique (e.g., Reinen and Weeks 1993; Blanpied et al. 1998) with Dieterich's rate- and state-dependent friction constitutive law (aging law) with one state variable (Dieterich 1979, 1981). In the constitutive law, the friction coefficient can be expressed as:

$$
\begin{aligned}
& \mu=\mu_{0}+a \ln \left(\frac{V}{V_{0}}\right)+b \ln \left(\frac{V_{0} \theta}{D_{c}}\right), \\
& \frac{\mathrm{d} \theta}{\mathrm{d} t}=1-\frac{V \theta}{D_{c}},
\end{aligned}
$$

where $\mu_{0}$ is the steady-state friction coefficient at a reference velocity $V_{0}, V$ is the sliding velocity after the velocity step from $V_{0}, \theta$ is the state variable, $D_{c}$ is the critical slip distance, and $a$ (direct effect) and $b$ (evolution effect) are constants. At a steady state $\left(d \theta / d t=0\right.$, and then $\left.V \theta=D_{c}\right)$, the friction coefficient is:

$$
\mu_{\mathrm{ss}}=\mu_{0}+(a-b) \ln \left(\frac{V}{V_{0}}\right) .
$$

Here, the velocity dependence of the friction is given by $\left(\mu_{\text {ss }}-\mu_{0}\right) / \ln \left(V / V_{0}\right)=a-b$. While a positive value of $(a-b)$ represents velocity-strengthening, which promotes a stable fault slip, velocity-weakening linked to a negative $(a-b)$ value is a necessity for the nucleation of unstable fault slips leading to earthquake generation (Marone 1998; Scholz 1998). Since the elastic interaction between the fault friction and the apparatus surrounding the sample was considered in the modeling, we obtained optimized values of the friction parameters as well as the apparatus stiffness from the inversion technique using the Levenberg-Marquardt method (Reinen and Weeks 1993; Noda and Shimamoto 2009; Takahashi et al. 2011). Also, we eliminated the background linear slip-hardening 
Table 1 List of optimized values of the friction parameters from inversion modeling for all experiments

\begin{tabular}{|c|c|c|c|c|c|c|c|c|c|c|}
\hline Run no. & $\begin{array}{l}\text { Normal } \\
\text { stress (MPa) }\end{array}$ & Velocity step ( $\mu \mathrm{m} / \mathrm{s})$ & Shear Disp. (mm) & $a$ & a.s.d. ${ }^{a}$ & $b$ & bs.d. ${ }^{a}$ & $D_{c}(\mu \mathrm{m})$ & $D_{c} s . d^{a}{ }^{a}(\mu \mathrm{m})$ & $a-b$ \\
\hline BASH155-01 & 2 & 1 to 0.1 & 2.96 & 0.0016 & 0.00096 & 0.0047 & 0.00044 & 16.2 & 8.54 & -0.0030 \\
\hline BASH155-02 & 2 & 0.1 to 1 & 3.49 & 0.0233 & 0.00504 & 0.0075 & 0.00028 & 27.2 & 1.41 & 0.0158 \\
\hline BASH155-03 & 2 & 1 to 10 & 3.99 & 0.0120 & 0.00158 & 0.0083 & 0.00019 & 28.9 & 1.27 & 0.0037 \\
\hline BASH155-04 & 2 & 10 to 100 & 4.28 & 0.0127 & 0.00355 & 0.0125 & 0.00103 & 26.3 & 3.49 & 0.0002 \\
\hline BASH155-05 & 2 & 100 to 10 & 4.58 & 0.0133 & 0.00360 & 0.0129 & 0.00121 & 10.6 & 2.16 & 0.0003 \\
\hline BASH155-06 & 2 & 10 to 1 & 4.89 & 0.0062 & 0.00061 & 0.0086 & 0.00030 & 11.5 & 0.83 & -0.0024 \\
\hline BASH155-07 & 2 & 1 to 0.1 & 5.39 & 0.0011 & 0.00069 & 0.0038 & 0.00036 & 21.3 & 13.6 & -0.0026 \\
\hline BASH155-08 & 2 & 0.1 to 1 & 5.92 & 0.0173 & 0.00264 & 0.0093 & 0.00019 & 15.2 & 0.45 & 0.0080 \\
\hline BASH155-09 & 2 & 1 to 10 & 6.42 & 0.0122 & 0.00141 & 0.0094 & 0.00029 & 13.1 & 0.61 & 0.0028 \\
\hline BASH155-10 & 2 & 10 to 100 & 6.72 & 0.0145 & 0.00392 & 0.0105 & 0.00155 & 14.5 & 2.92 & 0.0040 \\
\hline BASH155-11 & 2 & 100 to 10 & 7.05 & 0.0080 & 0.00244 & 0.0117 & 0.00078 & 16.4 & 2.89 & -0.0037 \\
\hline BASH155-12 & 2 & 10 to 1 & 7.35 & 0.0026 & 0.00045 & 0.0061 & 0.00018 & 20.5 & 2.49 & -0.0034 \\
\hline BASH156-01 & 5 & 1 to 0.1 & 2.92 & 0.0053 & 0.00005 & 0.0017 & 0.00001 & 14.5 & 0.76 & 0.0036 \\
\hline BASH156-02 & 5 & 0.1 to 1 & 3.45 & 0.0234 & 0.00047 & 0.0163 & 0.00050 & 2.0 & 0.06 & 0.0071 \\
\hline BASH156-03 & 5 & 1 to 10 & 3.96 & 0.0157 & 0.00023 & 0.0097 & 0.00025 & 4.1 & 0.13 & 0.0060 \\
\hline BASH156-04 & 5 & 10 to 100 & 4.25 & 0.0390 & 0.00088 & 0.0328 & 0.00089 & 1.5 & 0.05 & 0.0062 \\
\hline BASH156-05 & 5 & 100 to 10 & 4.54 & 0.0095 & 0.00011 & 0.0058 & 0.00004 & 35.0 & 0.51 & 0.0037 \\
\hline BASH156-06 & 5 & 10 to 1 & 4.86 & 0.0053 & 0.00007 & 0.0036 & 0.00004 & 21.8 & 0.38 & 0.0017 \\
\hline BASH156-07 & 5 & 1 to 0.1 & 5.36 & 0.0056 & 0.00004 & 0.0024 & 0.00002 & 61.9 & 0.62 & 0.0032 \\
\hline BASH156-08 & 5 & 0.1 to 1 & 5.90 & 0.0195 & 0.00017 & 0.0091 & 0.00012 & 2.8 & 0.04 & 0.0104 \\
\hline BASH156-09 & 5 & 1 to 10 & 6.39 & 0.0222 & 0.00079 & 0.0151 & 0.00084 & 2.5 & 0.14 & 0.0071 \\
\hline BASH156-10 & 5 & 10 to 100 & 6.69 & 0.0166 & 0.00056 & 0.0106 & 0.00057 & 5.3 & 0.36 & 0.0060 \\
\hline BASH156-11 & 5 & 100 to 10 & 7.10 & 0.0079 & 0.00007 & 0.0060 & 0.00003 & 32.8 & 0.36 & 0.0019 \\
\hline BASH156-12 & 5 & 10 to 1 & 7.41 & 0.0069 & 0.00006 & 0.0042 & 0.00003 & 26.8 & 0.35 & 0.0027 \\
\hline BASH153-01 & 10 & 1 to 0.1 & 1.91 & 0.0118 & 0.00180 & 0.0056 & 0.00150 & 0.1 & 0.02 & 0.0063 \\
\hline BASH153-02 & 10 & 0.1 to 1 & 2.45 & 0.0135 & 0.00034 & 0.0048 & 0.00015 & 5.5 & 0.17 & 0.0087 \\
\hline BASH153-03 & 10 & 1 to 10 & 2.95 & 0.0657 & 0.00004 & 0.0599 & 0.00071 & 0.4 & 0.05 & 0.0058 \\
\hline BASH153-04 & 10 & 10 to 100 & 3.24 & 0.0114 & 0.00343 & 0.0066 & 0.00254 & 11.3 & 6.30 & 0.0048 \\
\hline BASH153-05 & 10 & 100 to 10 & 3.52 & 0.0057 & 0.00058 & 0.0051 & 0.00023 & 31.0 & 2.77 & 0.0007 \\
\hline BASH153-06 & 10 & 10 to 1 & 3.83 & 0.0047 & 0.00029 & 0.0033 & 0.00011 & 32.8 & 2.88 & 0.0014 \\
\hline BASH153-07 & 10 & 1 to 0.1 & 4.33 & 0.0041 & 0.00032 & 0.0022 & 0.00013 & 47.9 & 7.68 & 0.0019 \\
\hline BASH153-08 & 10 & 0.1 to 1 & 4.87 & 0.0310 & 0.01481 & 0.0259 & 0.01486 & 0.8 & 0.46 & 0.0051 \\
\hline BASH153-09 & 10 & 1 to 10 & 5.37 & 0.0163 & 0.00264 & 0.0105 & 0.00278 & 4.1 & 1.20 & 0.0058 \\
\hline BASH153-10 & 10 & 10 to 100 & 5.67 & 0.0113 & 0.00328 & 0.0078 & 0.00243 & 9.4 & 4.50 & 0.0036 \\
\hline BASH153-11 & 10 & 100 to 10 & 5.98 & 0.0065 & 0.00080 & 0.0056 & 0.00031 & 24.2 & 2.92 & 0.0009 \\
\hline BASH153-12 & 10 & 10 to 1 & 6.30 & 0.0064 & 0.00038 & 0.0042 & 0.00013 & 30.7 & 2.03 & 0.0022 \\
\hline BASH157-01 & 20 & 1 to 0.1 & 2.90 & 0.0051 & 0.00002 & 0.0024 & 0.00001 & 66.6 & 0.86 & 0.0027 \\
\hline BASH157-02 & 20 & 0.1 to 1 & 3.44 & 0.0277 & 0.00024 & 0.0222 & 0.00025 & 2.1 & 0.02 & 0.0055 \\
\hline BASH157-03 & 20 & 1 to 10 & 3.94 & 0.0117 & 0.00007 & 0.0065 & 0.00006 & 9.3 & 0.12 & 0.0051 \\
\hline BASH157-04 & 20 & 10 to 100 & 4.23 & 0.0111 & 0.00028 & 0.0077 & 0.00019 & 13.5 & 0.48 & 0.0034 \\
\hline BASH157-05 & 20 & 100 to 10 & 4.63 & 0.0069 & 0.00007 & 0.0066 & 0.00003 & 40.4 & 0.38 & 0.0003 \\
\hline BASH157-06 & 20 & 10 to 1 & 4.94 & 0.0062 & 0.00003 & 0.0049 & 0.00001 & 46.6 & 0.23 & 0.0014 \\
\hline BASH157-07 & 20 & 1 to 0.1 & 5.44 & 0.0056 & 0.00002 & 0.0029 & 0.00001 & 55.0 & 0.19 & 0.0026 \\
\hline BASH157-08 & 20 & 0.1 to 1 & 5.98 & 0.0157 & 0.00039 & 0.0103 & 0.00041 & 3.5 & 0.15 & 0.0053 \\
\hline BASH157-09 & 20 & 1 to 10 & 6.48 & 0.0102 & 0.00009 & 0.0071 & 0.00007 & 7.3 & 0.12 & 0.0031 \\
\hline BASH157-10 & 20 & 10 to 100 & 6.77 & 0.0124 & 0.00042 & 0.0091 & 0.00034 & 8.4 & 0.48 & 0.0033 \\
\hline BASH157-11 & 20 & 100 to 10 & 7.05 & 0.0048 & 0.00006 & 0.0065 & 0.00002 & 37.8 & 0.31 & -0.0017 \\
\hline BASH157-12 & 20 & 10 to 1 & 7.37 & 0.0055 & 0.00003 & 0.0049 & 0.00001 & 33.4 & 0.21 & 0.0006 \\
\hline
\end{tabular}

a Standard deviation of friction parameters 
or slip-weakening trend from the displacement-friction curve data before performing the inversion analysis (Blanpied et al. 1998; Mair and Marone 1999; Takahashi et al. 2011). However, it is noted that this detrending procedure should be done with great care because it leads to uncertainty in the optimized values of the friction parameters.

\section{Results}

In the displacement vs shear stress curves of the tuff breccia samples deformed at normal stresses of 2 to $20 \mathrm{MPa}$, all samples exhibit a linear increase in shear stress to the yield point at a displacement of $\sim 0.3 \mathrm{~mm}$, then they reach a residual constant or slightly increasing trend at a steady state (Fig. 4a). Using data on the nor$\mathrm{mal}$ and shear stresses at a $1.5-\mathrm{mm}$ displacement where a quasi-steady-state is reached, we constructed the MohrCoulomb failure envelope for the frictional behavior of our samples (Byerlee 1978; Handin 1969) using the following expression:

$$
\tau=\mathrm{C}+\mu \cdot \sigma,
$$

where $\tau$ is shear stress, $\sigma$ is normal stress, and $C$ is cohesive strength (Fig. $4 \mathrm{~b}$ ). In this study, we corrected the friction coefficient considering $C=0.22 \mathrm{MPa}$, as derived from the linear regression between the normal versus shear stresses, while the apparent friction coefficient, in which $C$ is inevitably assumed to be zero, is frequently used in rock friction studies. Figure $4 \mathrm{c}$ shows the steadystate friction coefficient, which was calculated from the shear/normal stresses at a $1.5-\mathrm{mm}$ displacement using Eq. (4) and the $C$ value. The frictional coefficient of our breccia samples ranged between 0.40 and 0.47 , decreasing from the maximum $(\sim 0.47)$ to the minimum value $(\sim 0.40)$ as the normal stress increased from 2 to $10 \mathrm{MPa}$, followed by a slight increase to 0.43 at $20 \mathrm{MPa}$ (Fig. 4c).

Figure $5 \mathrm{a}$ shows the frictional response during the velocity step sequence $(0.1-1-10-100 \mu \mathrm{m} / \mathrm{s})$ at a range of normal stresses. A step increase or decrease in the sliding velocity by an order of magnitude after a steady state was achieved yielded a frictional response composed of an instantaneous increase or decrease in friction by $a \ln \left(V / V_{0}\right)$ and a subsequent gradual change by $b \ln \left(V / V_{0}\right)$ to a new steady state with increasing displacement, thereby obeying the rate and state friction law (Fig. 5b).

For the samples tested in the present study, a complex link exists between the velocity dependence of friction and the normal stress (Fig. 5c and Table 1). At a normal stress of $2 \mathrm{MPa}$, we observed a wide range of $(a-b)$ values between -0.037 and 0.016 . When the normal stress was increased up to $10 \mathrm{MPa}$, the sample exhibits velocity-strengthening behavior, with the values of $(a-b)$ ranging from $\sim 0$ to 0.010 . Then, $(a-b)$ decreases back to values of -0.002 to 0.005 at a normal stress of $20 \mathrm{MPa}$, corresponding to the stress at a depth of $2 \mathrm{~km}$. We observe a decreasing trend in the value of $(a-b)$ with an increasing normal stress except at $2 \mathrm{MPa}$, where significant scatter was observed. For $D_{c}$, our data show no systematic trend as the normal stress was increased, although the range of values becames wider $(\sim 60 \mu \mathrm{m})$ at higher normal stresses (Fig. 5d). Also, whereas several studies have reported that these friction parameters evolve with shear displacement (Mair and Marone 1999; Saffer and Marone 2003), no clear slip dependence of the friction parameters is documented in our data (Fig. 5e, f).

The deformed samples show monotonic microstructural change from localized shear deformation to distributed cataclastic flow with increasing normal stress (Fig. 6). For the sample deformed at $2 \mathrm{MPa}$, we observed a sharp boundary shear zone with a width of more than $150 \mu \mathrm{m}$ (this thickness is a minimum estimate because some grains can be lost during the preparation of thin sections) along the sample margin (Fig. 6a). In this zone, substantial fracturing and comminution of angular phenocrysts of plagioclase produced gouge materials with grain sizes less than tens of micrometers (Fig. 6b). Because most of the shear strain imposed during the experiment is likely to be accommodated by the boundary shear zone, other parts of the sample lack an obvious imprint of shear deformation. As the normal stress becomes greater, the shear deformation zone widens toward the interior of the sample, and the plagioclase grains located inside the zone are cataclastically deformed into small fragments aligned following the $\mathrm{P}$ orientation to form a distinct foliation (Logan et al. 1992; Passchier and Trouw 2005) (Fig. 6c, d). The brittle fracturing is observed dominantly in the plagioclase grains and rarely in the pyroxene grains. At a normal stress of $20 \mathrm{MPa}$, the degree of deformation accommodated by the boundary shearing decreases significantly, and inversely, the distributed deformation characterized by cataclastic foliations are more frequent across the entire width of the sample and the foliations are occasionally offset by Riedel micro-shear zones. The shear zones are composed of fine-grained gouges (commonly $<20 \mu \mathrm{m}$ ), and their thickness is approximately a few hundred micrometers (Fig. 6e, f). Both plagioclase and pyroxene grains are subjected to intense cataclasis under high stress conditions. For porous rocks, distributed cataclastic deformation is often associated with strain hardening, while localized shear deformation is associated with strain weakening (Wong and Baud 2012). Thus, the slip hardening/weakening trends observed in our samples might be related to the transition of deformation mode, although additional research is clearly needed. 

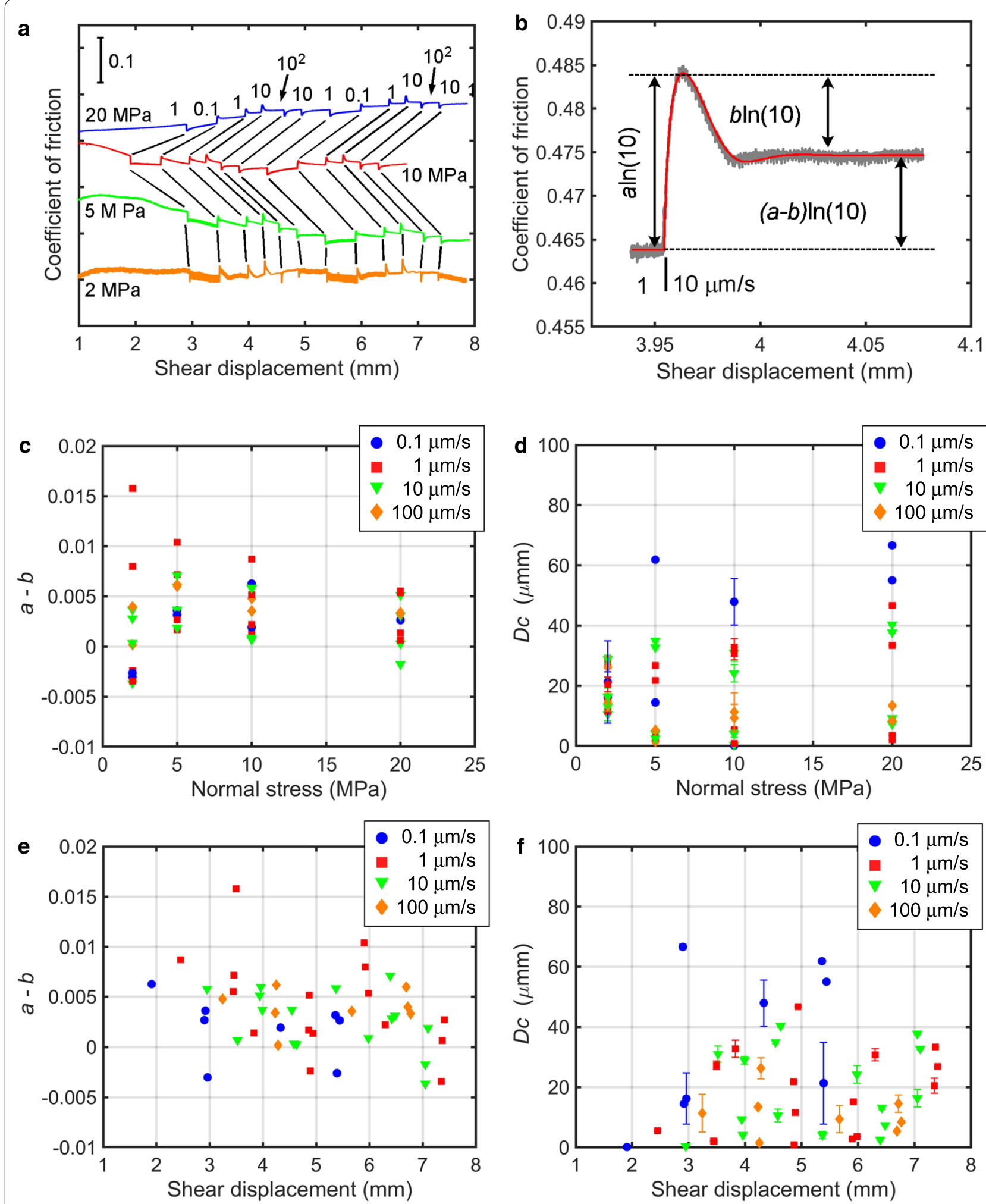

Fig. 5 Experimental data and the friction parameter modeling results. a Friction as a function of shear displacement with velocity steps between 0.1 and $100 \mathrm{\mu m} / \mathrm{s}$ at normal stresses of 2, 5, 10 and $20 \mathrm{MPa}$. Curves are offset vertically for clarity. $\mathbf{b}$ An example of the friction response to a velocity step from 1 to $10 \mu \mathrm{m} / \mathrm{s}$ (gray) with a best-fitting curve obtained by inversion analysis (red). c Velocity-dependent friction parameter ( $a-b)$ and $\mathbf{d}$ critical slip distance $D_{c}$ plotted as a function of normal stress for all velocity steps (blue circle, $0.1 \mu \mathrm{m} / \mathrm{s}$; red square, $1 \mu \mathrm{m} / \mathrm{s}$; green triangle, $10 \mu \mathrm{m} / \mathrm{s}$; orange diamond, $100 \mu \mathrm{m} / \mathrm{s}$ ) 

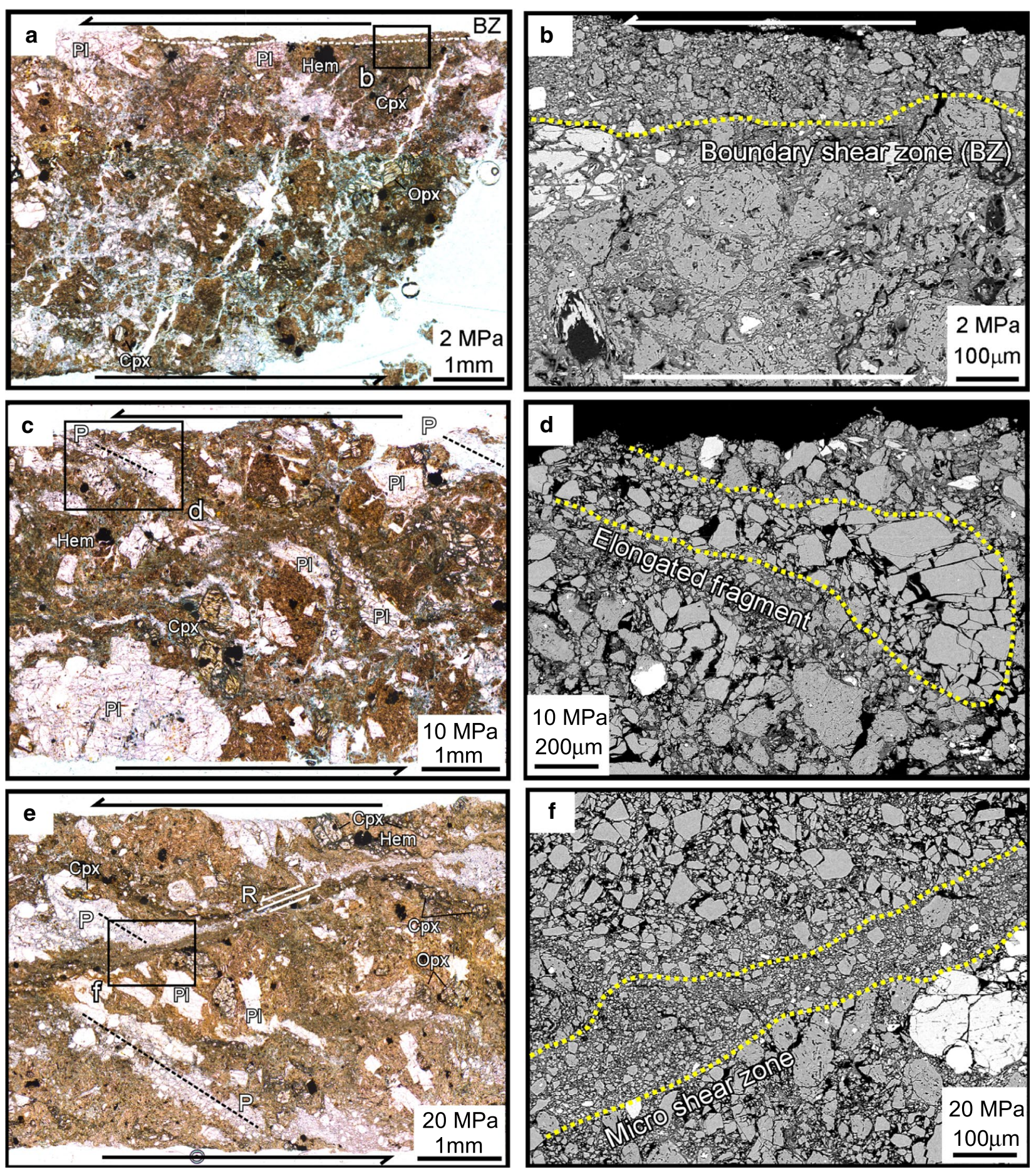

Fig. 6 Microstructures of the deformed samples after the velocity-stepping friction tests at normal stresses of $\mathbf{a}, \mathbf{b} 2 \mathrm{MPa}, \mathbf{c}, \mathbf{d} 10 \mathrm{MPa}$ and $\mathbf{e}, \mathbf{f}$ $20 \mathrm{MPa}$, under optical $(\mathbf{a}, \mathbf{c}, \mathbf{f})$ and electron $(\mathbf{b}, \mathbf{d}, \mathbf{f})$ microscopes. Shear sense is top-to-the-left. a The boundary shear zone (BZ), the lower boundary of which is delimited by the dotted white line, is located along the upper edge of the sample. The black box gives the position of $\mathbf{b}$. $\mathbf{b}$ A close-up view of the boundary shear zone characterized by $<20 \mu \mathrm{m}$ small grains, located above the dotted yellow line. c The dotted lines indicate cataclastic P foliations formed in the upper part of the sample. The black box gives the position of $\mathbf{d}$. $\mathbf{d}$ A close-up view of elongated plagioclase fragments, demarcated by the dotted yellow line, forming the cataclastic foliation. $\mathbf{e}$ The $P$ foliation (dotted lines) is pervasive across the bulk sample, and sometimes offset by left-lateral Riedel shears (solid white line). The black box gives the position of $\mathbf{f}$. $\mathbf{f}$ A close-up view of the Riedel micro-shear zone bounded by the dotted yellow lines. Pl, plagioclase; Opx, orthopyroxene; Cpx, clinopyroxene; Hem, hematite 


\section{Discussion}

We examined the velocity dependence of friction under a range of normal stresses from 2 to $20 \mathrm{MPa}$ for the sedimentary cover in the shallow part of the crust. The porous tuff breccia samples are characterized by predominantly velocity-strengthening behavior, and they show a slightly decreasing trend of velocity dependence as the normal stress is increased from 5 to $20 \mathrm{MPa}$. Experimental studies have found that the velocity dependence of friction varies with normal stress (e.g., Mair and Marone 1999; Saffer and Marone 2003; Niemeijer and Collettini 2014; Carpenter et al. 2016; Sawai et al. 2016; Morrow et al. 2017). The data on powdered gouge prepared from kaolinite-rich claystone by Orellana et al. (2018) and on smectite-rich natural fault gouge by Carpenter et al. (2015) have shown that mostly velocity-strengthening behavior is apparent at normal stresses below $100 \mathrm{MPa}$, with a decreasing trend in $(a-b)$ displayed in some cases at low normal stresses of less than $40 \mathrm{MPa}$. Our samples exhibit similar positive velocity dependence and showed a decrease of velocity dependence with normal stress, which is likely to be due to the presence of clay mineral (smectite) contained in the sample. In addition, friction experiments performed by Ikari et al. (2011a) on a range of gouge materials demonstrated a correlation between the velocity dependence of friction and the frictional strength. At coefficients of friction less than 0.5, $(a-b)$ was always positive, a finding that is roughly consistent with our results (Fig. 4c).

Next, we discuss the relationship between the velocitydependent frictional property and the microstructures observed in our samples. Several studies have suggested that rocks exhibiting velocity-weakening behavior show localized shearing, whereas a widely distributed deformation fabric is present in those exhibiting velocitystrengthening behavior (Beeler et al. 1996; Mair and Marone 1999). Our deformed samples are characterized by a systematic change in the deformation fabric from shear localization to distributed cataclastic flow as a function of normal stress (Fig. 6), but we do not observe any apparent correlation between the microstructures and friction velocity dependence, as was suggested in previous observations. The sample at $2 \mathrm{MPa}$, where most of the shear occurs in the boundary zone, shows some negative $(a-b)$ values, but showed mainly velocity-strengthening behavior. In the 20-MPa case in which shear-localized Riedel shear zones are developed, only one case of velocity-weakening is observed. It is suggested that Riedel shears may encourage the velocity-weakening behavior (Ikari et al. 2011b). Although we believe that the microstructural localization/delocalization features seem to have a partial correlation with the friction velocity dependence in our results, further investigations are required to fully elucidate the mechanism responsible for the stress-dependent frictional properties observed in the porous tuff breccia.

Our velocity-stepping friction experiments at elevated pressures provide a better quantitative estimate of the stress-variable, namely depth-variable, distribution of friction velocity dependence in a shallow crustal zone in the Japan arc islands, where the subsurface lithology is frequently dominated by thick sediment deposits. Therefore, these findings provide some insights into its mechanical role for earthquake rupture dynamics. Note that the effect of temperature on the frictional properties was not considered in this work because the temperature at the shallow depths is relatively low $\left(<60{ }^{\circ} \mathrm{C}\right)$, but the effect should be investigated in future research.

With our results that the tuff breccia sample exhibits mostly frictionally stable, velocity-strengthening behavior, we confirm the widely accepted hypothesis that a shallow crustal layer behaves predominantly as a barrier for dynamic (unstable) rupture propagation from the seismogenic zone during an earthquake. This finding explains the upper limit of the seismogenic zone's width and the emergence of a shallow slip deficit (Wald and Heaton 1994; Simons et al. 2002; Fialko et al. 2005). The aftershock distribution of the 2007 Noto Hanto earthquake near the study area shows that the seismogenic zone has an upper bound defined by the approximately 2-km-thick sediment layer composed of the Miocene volcaniclastic deposits from which our sample was collected (Kato et al. 2008). This is consistent with the seismically stable properties obtained in the experiments. Furthermore, for the 2004 mid-Niigata prefecture earthquake, which also occurred in the "Green Tuff" region, the associated surface slip was an order of magnitude smaller than the slip at depth estimated from seismic data (Maruyama et al. 2005). This was interpreted as a shallow slip deficit due to thick sediment cover, a conclusion that is implicitly supported by our laboratory data. However, the present results obtained at low slip velocities do not exclude the possibility that earthquake rupture propagation could runaway through a shallow layer that exhibits a velocity-strengthening at the low slip rates when a dynamic weakening mechanism is activated at coseismic slip rates (Di Toro et al. 2011; Noda and Lapusta 2013).

\section{Conclusions}

To examine the frictional properties of a shallow sediment layer, we performed velocity-stepping friction tests on porous tuff breccia samples from the Miocene "Green Tuff" formation, a major sediment deposit in Japan, at normal stresses of 2 to $20 \mathrm{MPa}$. The experimental results document that the samples exhibit mostly velocitystrengthening behavior with a slightly decreasing trend 
in $(a-b)$ as normal stress increases. The frictionally stable properties are in accordance with the observations that earthquakes occurring in the "Green Tuff" area are characterized by low seismicity and the occurrence of a shallow slip deficit in the shallow zone. Microstructural analyses of the postmortem samples reveal that the deformation fabric transitions from shear localization to distributed cataclastic flow with increasing normal stress. In our samples, however, we do not observe a clear relationship between microstructures and friction velocity dependence as previously reported. We suggest that laboratory investigations, such as that presented here, can illuminate in detail the depth-variable distribution of the friction velocity dependence of a shallow sediment layer. Our findings, in combination with further investigations on a variety of subsurface sediment materials, could facilitate a comprehensive understanding of the mechanical role of a shallow sediment layer for earthquake rupture dynamics and shallow seismicity.

\section{Acknowledgements}

We acknowledge the Hokuriku Electric Power Co., Ltd. for providing the fresh core samples used in the friction experiments. We are grateful to T. lida and T. Taniguchi for assisting with the experiments and thin section preparation. Figures were drawn using Generic Mapping Tools (Wessel et al. 2013). The reviews by Kyu Kanagawa and an anonymous reviewer greatly helped us to improve the manuscript.

\section{Authors' contributions}

KM planned the study, interpreted the experimental data, and drafted the manuscript. SU and SI performed the friction experiments and analyzed the data. TH contributed to the microstructural analysis of the samples and provided useful discussions. All authors read and approved the final manuscript.

\section{Funding}

This study was financially supported by the general operating expenses of the Central Research Institute of Electric Power Industry (CRIEPI).

\section{Availability of data and materials}

All experimental raw data are publicly available in a repository (at https:// zenodo.org/record/4047766\#.X31NZmgzaUk).

\section{Declarations}

\section{Competing interests}

The authors declare that they have no competing interests.

\section{Author details}

${ }^{1}$ Central Research Institute of Electric Power Industry, 1646 Abiko, Abiko, Chiba 270-1194, Japan. ${ }^{2}$ Graduate School of Science, Toho University, 2-2-1 Miyama, Funabashi, Chiba 274-8510, Japan. ${ }^{3}$ Kochi Institute for Core Sample Research, Japan Agency for Marine-Earth Science and Technology, 200 Monobe Otsu, Nankoku, Kochi 783-8502, Japan. ${ }^{4}$ CERES Inc., 1646 Abiko, Abiko, Chiba 270-1194, Japan.

Received: 28 December 2020 Accepted: 13 April 2021

Published online: 29 April 2021

\section{References}

Beeler NM, Tullis TE, Blanpied ML, Weeks JD (1996) Frictional behavior of large displacement experimental faults. J Geophys Res 101:8697-8715. https:// doi.org/10.1029/96JB00411
Blanpied ML, Lockner DA, Byerlee JD (1991) Fault stability inferred from granite sliding experiments at hydrothermal conditions. Geophys Res Lett 18:609-612. https://doi.org/10.1029/91gl00469

Blanpied ML, Marone CJ, Lockner DA, Byerlee JD, King DP (1998) Quantitative measure of the variation in fault rheology due to fluid-rock interactions. J Geophys Res 103:9691-9712. https://doi.org/10.1029/98JB00162

Boulton C, Carpenter BM, Toy V, Marone C (2012) Physical properties of surface outcrop cataclastic fault rock, Alpine Fault, New Zealand. Geochem Geophys Geosyst 13:Q01018. https://doi.org/10.1029/2011GC003872

Brune JN, Anooshehpoor A (1998) A physical model of the effect of a shallow weak layer on strong ground motion for strike-slip ruptures. Bull Seismol Soc Am 88:1070-1078. https://doi.org/10.2172/776519

Byerlee J (1978) Friction of rocks. Pure Appl Geophys 116:615-626. https://doi. org/10.1007/BF00876528

Carpenter BM, Marone C, Saffer DM (2011) Weakness of the San Andreas Fault revealed by samples from the active fault zone. Nat Geosci 4:251-254. https://doi.org/10.1038/NGEO1089

Carpenter BM, Saffer DM, Marone C (2015) Frictional properties of the active San Andreas Fault at SAFOD: implications for fault strength and slip behavior. J Geophys Res 120:5273-5289. https://doi.org/10.1002/2015J B011963

Carpenter BM, Collettini C, Viti C, Cavallo A (2016) The influence of normal stress and sliding velocity on the frictional behavior of calcite at room temperature: insights from laboratory experiments and microstructural observations. Geophys J Int 205:548-561. https://doi.org/10.1093/gji/ ggw038

Das S, Scholz CH (1983) Why large earthquakes do not nucleate at shallow depths. Nature 305:621-623. https://doi.org/10.1038/305621a0

Day SM, Ely GP (2002) Effect of a shallow weak zone on fault rupture: numerical simulation of scale-model experiments. Bull Seismol Soc Am 92:3022-3041

Di Toro G, Han R, Hirose T, Paola ND, Nielsen S, Mizoguchi K, Ferri F, Cocco M, Shimamoto T (2011) Fault lubrication during earthquakes. Nature 471:494-498. https://doi.org/10.1038/nature09838

Dieterich JH (1979) Modeling of rock friction, 1. Experimental results and constitutive equations. J Geophys Res 84:2161-2168. https://doi.org/10. 1029/JB084iB05p02161

Dieterich JH (1981) Constitutive properties of faults with simulated gouge. In: Carter NL, Friedman M, Logan JM, Stearns DW (eds) Mechanical behavior of crustal rocks, geophysical monograph series, vol 24. Ameican Geophysical Union, Washington, D.C., pp 103-120. https://doi.org/10.1029/ GM024p0103

Doser DI, Kanamori H (1986) Depth of seismicity in the Imperial Valley region (1977-1983) and its relationship to heat flow, crustal structure and the October 15, 1979 earthquake. J Geophys Res 91:675-688. https://doi.org/ 10.1029/JB091iB01 p00675

Fialko Y, Sandwell D, Simons M, Rosen P (2005) Three-dimensional deformation caused by the Bam, Iran, earthquake and the origin of shallow slip deficit. Nature 435:295-299. https://doi.org/10.1038/nature03425

Fredrich JT, Evans B, Wong T-F (1989) Micromechanics of the brittle to plastic transition in Carrara marble. J Geophys Res 94:4129-4145. https://doi.org/ 10.1029/JB094iB04p04129

Fujiwara T, Kodaira S, No T, Kaiho Y, Takahashi N, Kaneda Y (2011) The 2011 Tohoku-Oki earthquake: displacement reaching the trench axis. Science 334:1240. https://doi.org/10.1126/science.1211554

Handin J (1969) On the Coulomb-Mohr failure criterion. J Geophys Res 74:5343-5348. https://doi.org/10.1029/JB074i022p05343

Huzioka K (1963) Geology of the Green Tuff region in Japan. Min Geol 13:358375. https://doi.org/10.11456/shigenchishitsu1951.13.62_358.inJapanese

Hyndman RD, Yamano M, Oleskevich DA (1997) The seismogenic zone of subduction thrust faults. Island Arc 6:244-260. https://doi.org/10.1111/j. 1440-1738.1997.tb00175.x

Ikari MJ, Marone C, Saffer DM (2011a) On the relation between fault strength and frictional stability. Geology 39:83-86. https://doi.org/10.1130/ G31416.1

Ikari MJ, Niemeijer AR, Marone C (2011 b) The role of fault zone fabric and lithification state on frictional strength, constitutive behavior, and deformation microstructure. J Geophys Res 116:B08404. https://doi.org/10. 1029/2011JB008264 
Ikari MJ, Ito Y, Ujiie K, Kopf AJ (2015) Spectrum of slip behaviour in Tohoku fault zone samples at plate tectonic slip rates. Nat Geosci 8:870-874. https:// doi.org/10.1038/ngeo2547

Ito K (1999) Seismogenic layer, reflective lower crust, surface heat flow and large inland earthquakes. Tectonophysics 306:423-433. https://doi.org/ 10.1016/S0040-1951(99)00069-4

Ito Y, Tsuji T, Osada Y, Kido M, Inazu D, Hayashi Y, Tsushima H, Hino R, Fujimoto $H$ (2011) Frontal wedge deformation near the source region of the 2011 Tohoku-oki earthquake. Geophys Res Lett. https://doi.org/10.1029/2011G L048355

Kaneko Y, Fialko Y (2011) Shallow slip deficit due to large strike-slip earthquakes in dynamic rupture simulations with elasto-plastic off-fault response. Geophys J Int 186:1389-1403. https://doi.org/10.1111/j.1365246X.2011.05117.x

Kano K, Uto K, Ohguchi T (2007) Stratigraphic review of Eocene to Oligocene successions along the eastern Japan Sea: implication for early opening of the Japan Sea. J Asian Earth Sci 30:20-32. https://doi.org/10.1016/j.jseaes. 2006.07.003

Kaseno Y (1965) Geology of the Noto Peninsula. In Science research. Report of the Noto Peninsula (Gakujutsu Chosa Hokokusho). Ishikawa Prefectural Government, Kanazawa, Japan (in Japanese with English abstract)

Kato A, Sakai S, lidaka T, Iwasaki T, Kurashimo E, Igarashi T, Hirata N, Kanazawa T, Group for the aftershock observations of the 2007 Noto Hanto Earthquake (2008) Three-dimensional velocity structure in the source region of the Noto Hanto Earthquake in 2007 imaged by a dense seismic observation. Earth Planets Space 60:105-110. https://doi.org/10.1186/ BF03352769

Kikuchi Y, Tono S, Funayama M (1991) Petroleum resources in the Japanese island-arc setting. Episodes 14:236-241. https://doi.org/10.18814/epiiu gs/1991/v14i3/007

Kodaira S, No T, Nakamura Y, Fujiwara T, Kaiho Y, Miura S, Takahashi N, Kaneda Y, Taira A (2012) Coseismic fault rupture at the trench axis during the 2011 Tohoku-oki earthquake. Nat Geosci 5:646-650. https://doi.org/10.1038/ ngeo1547

Logan JM, Dengo CA, Higgs NG, Wang ZZ (1992) Fabrics of experimental fault zones: their development and relationship to mechanical behavior. In: Evans B, Wong T-F (eds) Fault mechanics and transport properties of rocks. Academic Press, San Diego, pp 33-67. https://doi.org/10.1016/ S0074-6142(08)62814-4

Maggi A, Jackson J, McKenzie D, Priestley K (2000) Earthquake focal depths, effective elastic thickness, and the strength of the continental lithosphere. Geology 28:495-498. https://doi.org/10.1130/0091-7613(2000) 28\%3c495:EFDEET\%3e2.0.CO;2

Mair K, Marone C (1999) Friction of simulated fault gouge for a wide range of velocities and normal stresses. J Geophys Res 104:28899-28914. https:// doi.org/10.1029/1999JB900279

Marone C (1998) Laboratory-derived frictional laws and their application to seismic faulting. Annu Rev Earth Planet Sci 94:12321-12335. https://doi. org/10.1146/annurev.earth.26.1.643

Marone C, Scholz CH (1988) The depth of seismic faulting and the upper transition from stable to unstable slip regimes. Geophys Res Lett 15:621-624. https://doi.org/10.1029/GL015i006p00621

Marone C, Scholz CH, Bilham R (1991) On the mechanics of earthquake afterslip. J Geophys Res 96:8441-8452. https://doi.org/10.1029/91JB00275

Maruyama T, Fusejima Y, Yoshioka T, Awata Y, Matsu'ura T (2005) Characteristics of the surface rupture associated with the 2004 Mid Niigata Prefecture earthquake, central Japan and their seismotectonic implications. Earth Planets Space 57:521-526. https://doi.org/10.1186/BF03352586

Matsuda T (1977) Estimation of future destructive earthquakes from active faults on land in Japan. J Phys Earth 25:S251-S260. https://doi.org/10. 4294/jpe1952.25.Supplement_S251

Moore GF, Bangs NL, Taira A, Kuramoto S, Pangborn E, Tobin HJ (2007) Three-dimensional splay fault geometry and implications for Tsunami generation. Science 318:1128-1131. https://doi.org/10.1126/science. 1147195

Morrow CA, Moore DE, Lockner DA (2017) Frictional strength of wet and dry montmorillonite. J Geophys Res 122:3392-3409. https://doi.org/10. 1002/2016JB013658

Murata Y, Kano K (1995) The areas of the geologic units comprising the Japanese Islands, calculated by using the Geological Map of Japan
1:1,000,000, 3rd Edition, CD-ROM version. Chishitsu News 493:26-29 (in Japanese)

Nazareth JJ, Hauksson E (2004) The seismogenic thickness of the Southern California crust. Bull Seismol Soc Am 94:940-960. https://doi.org/10. 1785/0120020129

Niemeijer AR, Collettini C (2014) Frictional properties of a low-angle normal fault under in situ conditions: thermally-activated velocity weakening. Pure Appl Geophys 171:2641-2664. https://doi.org/10.1007/ s00024-013-0759-6

Niemeijer AR, Boulton C, Toy VG, Townend J, Sutherland R (2016) Largedisplacement, hydrothermal frictional properties of DFDP-1 fault rocks, Alpine Fault, New Zealand: implications for deep rupture propagation. J Geophys Res 121:624-647. https://doi.org/10.1002/2015JB012593

Noda H, Lapusta N (2013) Stable creeping fault segments can become destructive as a result of dynamic weakening. Nature 493:518-521. https://doi.org/10.1038/nature11703

Noda H, Shimamoto T (2009) Constitutive properties of clayey fault gouge from the Hanaore fault zone, southwest Japan. J Geophys Res 114:B04409. https://doi.org/10.1029/2008JB005683

Orellana LF, Scuderi MM, Collettini C, Violay M (2018) Frictional properties of Opalinus Clay: implications for nuclear waste storage. J Geophys Res 123:157-175. https://doi.org/10.1002/2017JB014931

Ozaki M, Komazawa M, Inoue T (2010) 1:2000,000 Geological map with gravity contours in and around the northern part of Noto Peninsula. In Seamless geoinformation of coastal zone "Nothern coastal zone of Noto Peninsula" (Digital Geoscience Map S-1). Geological survey of Japan, AIST, Tsukuba. https://www.gsj.jp/researches/project/coastalgeology/results/s-1.html. Accessed 23 Dec 2020

Passchier CW, Trouw RAJ (2005) Microtectonics, 2nd edn. Springer, Berlin. https://doi.org/10.1007/3-540-29359-0

Pitarka A, Dalquer LA, Day SM, Somerville PG, Dan K (2009) Numerical study of ground-motion differences between buried-rupturing and surfacerupturing earthquakes. Bull Seismol Soc Am 99:1521-1537. https://doi. org/10.1785/0120080193

Reinen LA, Weeks JD (1993) Determination of rock friction constitutive parameters using an iterative least squares inversion method. J Geophys Res 98:15937-15950. https://doi.org/10.1029/93JB00780

Rice JR (1993) Spatio-temporal complexity of slip on a fault. J Geophys Res 98:9885-9907. https://doi.org/10.1029/93JB00191

Ruina A (1983) Slip instability and state variable friction laws. J Geophys Res 88:10359-10370. https://doi.org/10.1029/JB088BB12p10359

Saffer DM, Marone C (2003) Comparison of smectite- and illite-rich gouge frictional properties: application to the updip limit of the seismogenic zone along subduction megathrusts. Earth Planet Sci Lett 215:219-235. https://doi.org/10.1016/S0012-821X(03)00424-2

Sato H, Amano K (1991) Relationship between tectonics, volcanism, sedimentation and basin development, Late Cenozoic, central part of Northern Honshu, Japan. Sediment Geol 74:323-343. https://doi.org/ 10.1016/0037-0738(91)90071-K

Sawai M, Niemeijer AR, Plümper O, Hirose T, Spiers CJ (2016) Nucleation of frictional instability caused by fluid pressurization in subducted blueschist. Geophys Res Lett 43:2543-2551. https://doi.org/10.1002/ 2015GL067569

Sawai M, Niemeijer AR, Hirose T, Spiers CJ (2017) Frictional properties of JFAST core samples and implications for slow earthquakes at the Tohoku subduction zone. Geophys Res Lett 44:8822-8831. https://doi.org/10.1002/ 2017GL073460

Scholz CH (1998) Earthquakes and friction laws. Nature 391:37-42. https://doi. org/10.1038/34097

Sibson RH (1982) Fault zone models, heat flow, and the depth distribution of earthquakes in the continental crust of the United States. Bull Seismol Soc Am 72:151-163

Sibson RH (1983) Continental fault structure and the shallow earthquake source. J Geol Soc Lond 140:741-767. https://doi.org/10.1144/gsjgs.140.5. 0741

Simons M, Fialko Y, Rivera L (2002) Coseismic deformation from the 1999 MW $_{W}$ 7.1 Hector Mine, California, earthquake as inferred from InSAR and GPS observations. Bull Seismol Soc Am 92:1390-1402

Somerville PG (2003) Magnitude scaling of the near fault rupture directivity pulse. Phys Earth Planet Int 137:201-212. https://doi.org/10.1016/S00319201(03)00015-3 
Takahashi M, Uehara S, Mizoguchi K, Shimizu I, Okazaki K, Masuda K (2011) On the transient response of serpentine (antigorite) gouge to stepwise changes in slip velocity under high-temperature conditions. J Geophys Res 116:B10405. https://doi.org/10.1029/2010JB008062

Tse ST, Rice R (1986) Crustal earthquake instability in relation to the depth variation of frictional slip properties. J Geophys Res 91:9452-9472. https:// doi.org/10.1029/JB091iB09p09452

Ujiie K, Tanaka H, Saito T, Tsutsumi A, Mori JJ, Kameda J, Brodsky EE, Chester FM, Eguchi N, Toczko S, Expedition 343 and 343 T Scientists (2013) Low coseismic shear stress on the Tohoku-Oki megathrust determined from laboratory experiments. Science 342:1211-1214. https://doi.org/10.1126/ science.1243485

Verberne BA, He C, Spiers CJ (2010) Frictional properties of sedimentary rocks and natural fault gouge from the Longmenshan Fault Zone, Sichuan, China. Bull Seismol Soc Am 100:2767-2790. https://doi.org/10.1785/ 0120090287

von Huene R, Langseth M, Nasu N, Okuda H (1982) A summary of Cenozoic tectonic history along the IPOD Japan Trench transect. Geol Soc Am Bull 93:829-846. https://doi.org/10.1130/0016-7606(1982)93\%3c829: ASOCTH\%3e2.0.CO;2
Wald DJ, Heaton TH (1994) Spatial and temporal distribution of slip for the 1992 Landers, California, earthquake. Bull Seismol Soc Am 84:668-691 Wesnousky SG, Scholz CH, Shimazaki K, Matsuda T (1984) Integration of geological and seismological data for the analysis of seismic hazard: A case study of Japan. Bull Seismol Soc Am 74:687-708

Wessel P, Smith WHF, Scharroo R, Luis JF, Wobbe F (2013) Generic Mapping Tools: Improved version released. Eos Trans Am Geophys Union 94:409-410. https://doi.org/10.1002/2013EO450001

Wong TF, Baud P (2012) The brittle-ductile transition in porous rock: a review. J Struct Geol 44:25-53. https://doi.org/10.1016/j.jsg.2012.07.010

Zinke R, Hollingsworth J, Dolan JF (2014) Surface slip and off-fault deformation patterns in the $2013 \mathrm{M}_{\mathrm{W}} 7.7$ Balochistan, Pakistan earthquake: Implications for controls on the distribution of near-surface coseismic slip. Geochem Geophys Geosyst 15:5034-5050. https://doi.org/10.1002/ 2014GC005538

\section{Publisher's Note}

Springer Nature remains neutral with regard to jurisdictional claims in published maps and institutional affiliations.

\section{Submit your manuscript to a SpringerOpen ${ }^{\circ}$ journal and benefit from:}

- Convenient online submission

- Rigorous peer review

- Open access: articles freely available online

- High visibility within the field

- Retaining the copyright to your article

Submit your next manuscript at $\boldsymbol{\nabla}$ springeropen.com 